\title{
Comparison of Intravenous Ondansetron versus Intravenous Tramadol on Post-Spinal Shivering and Nausea/Vomiting in Cesarean Sections
}

Sanum Kashif ${ }^{1}$, Faisal Azam ${ }^{1}$, Khalid Mehmood ${ }^{2}$, Saira Tasneem ${ }^{1}$, Asad Shamim ${ }^{2}$, Fawad Alam ${ }^{2}$, Tasneem Alam $^{2}$

\section{ABSTRACT}

Objective: To compare the effect of intravenous ondansetron versus intravenous tramadol on post-spinal shivering and nausea/vomiting in caesarean sections.

Study Design: Prospective comparative study

Place and Duration of study: The study was carried out at Department of Anesthesia, Frontier Corps Hospital Quetta from $2^{\text {nd }}$ July 2019 to $1^{\text {st }}$ November 2019.

Materials and Methods: Ninety patients, who were scheduled for elective cesarean section under spinal anesthesia were randomly allocated to one of three study groups to receive intravenous ondansetron (group O), tramadol (group T) or normal saline/placebo (group P). Intra- and post-operative shivering score, nausea/vomiting score and hemodynamic changes were recorded. Descriptive data was expressed as means and standard deviations (SD). Analysis of variance (ANOVA) and repeated measure analysis were used for continuous parametric variables. Within groups, comparisons were made using the Tukey's post-hoc analysis. Chi-square test was used for association of shivering and nausea/vomiting among the groups.

Results: Both groups were comparable for the age and weight. Shivering was reported $0.35 \pm 0.59$ in ondansetron group $0.73 \pm 0.55$ in Tramadol group and $1.90 \pm 0.84$ in Placebo group ( $p$ value $<0.001$ ). Postoperative nausea and vomiting (PONV) was reported $0.25 \pm 0.53$ in ondansetron group $1.04 \pm 0.63$ in tramadol group and $0.99 \pm 0.71$ in placebo group ( $p$ value $<0.001$ ). There was a significant difference in postspinal shivering and nausea/vomiting in ondansetron $(\mathrm{O})$ group versus tramadol $(\mathrm{T})$ group and placebo group.

Conclusion: The effect of intravenous ondansetron is better than intravenous tramadol in preventing shivering as well as nausea/vomiting.

\section{Key Words: Cesarean Section, Shivering, Nausea/Vomiting, Ondansetron, Spinal Anesthesia, Tramadol.}

How to cite this: Kashif S, Azam F, Mehmood K, Tasneem S, Shamim A, Alam F, Alam T. Comparison of Intravenous Ondansetron versus Intravenous Tramadol on Post-Spinal Shivering and Nausea/Vomiting In Cesarean Sections. Life and Science. 2020; 1(4): 156-161. doi: http://doi.org/10.37185/LnS.1.1.102

This is an Open Access article distributed under the terms of the Creative Commons Attribution License (http://creativecommons.org/licenses/by/4.0), which permits unrestricted use, distribution, and reproduction in any medium, provided the original work is properly cited.

\section{Introduction}

Shivering is one of the common complications of anesthesia. It leads to increase oxygen consumption and increases the risk of hypoxemia and lactic acidosis which increases the catecholamine release

${ }^{1}$ Department of Anesthesia

Frontier Corps Hospital, Quetta

${ }^{2}$ Department of Anesthesia

Combined Military Hospital, Quetta

Correspondence:

Maj Dr. Sanum Kashif

Department of Anesthesia

Frontier Corps Hospital, Quetta

E-mail: sanumdr@gmail.com

Funding Source: NIL; Conflict of Interest: NIL

Received: Feb 15, 2020; Revised: Jun 04, 2020

Accepted: Sep 18, 2020 and hemodynamic instability. Therefore, it might increase the postoperative complications especially in high-risk patients. Moreover, shivering is one of the leading causes of discomfort for postsurgical patients. ${ }^{1}$ In previous studies, various techniques have been used to alleviate the postoperative shivering. ${ }^{2}$

We compared the effect of single dose of intravenous ondansetron versus tramadol on shivering and nausea/vomiting in patients undergoing cesarean section under spinal anesthesia.

Intra- and postoperative shivering remain the common problem after surgery under spinal anesthesia. Shivering may increase cardiac output, circulating catecholamines, intracranial and 
intraocular pressures, and blood pressures. Hemodynamic stability is very important in all surgeries, especially in caesarean sections where two lives are involved. Profound hemodynamic alterations due to shivering may cause deleterious effects. ${ }^{3}$ In a review of twenty one studies, median incidence of shivering related to spinal anesthesia was reported as 55\%. ${ }^{4}$ Furthermore, it is considered responsible for exacerbating postoperative pain and patient discomfort. Pain control after cesarean section improves breastfeeding and mother satisfaction. In addition, postoperative pain is associated with neuroendocrine responses. Postspinal shivering could be a provocative factor for postoperative pain and its appropriate treatment prevents non-thermoregulatory tremors. ${ }^{5}$ Shivering also causes aggravating of postoperative pain by stretching of sutures. Several techniques are used for the prevention and treatment of post-spinal shivering, such as administration of meperidine, buspirone, nefopam, clonidine, alfentanil, dolasetron, ketanserin, doxapram, and dexmedetomidine. ${ }^{6,7}$

Ondansetron is a selective antagonist for receptor 5hydroxytryptamine 3 and is very effective in the prevention and treatment of shivering intra- and post-operation. This medicine also decreases nausea and vomiting intra- and post-operatively. Ondansetron can affect the body temperature and shivering in rats since the balance of nor-epinephrine and 5-hydroxytryptamine (5-HT) in the preopticanterior hypothalamus controls the temperature set point. Consistently, several studies have demonstrated ondansetron can prevent shivering, which made it a promising drug for postoperative

\begin{tabular}{cl}
\hline Table 1: Classification of shivering \\
\hline Grade & Grade \\
0 & No shivering \\
1 & Mild fasciculations of face or neck \\
2 & Visible tremor involving more than one muscle \\
3 & group \\
\hline Score & Nausea and vomiting degree \\
0 & No nausea, no vomiting \\
1 & Nausea present, no vomiting \\
2 & Nausea present, vomiting present \\
3 & Vomiting $>2$ episodes in 30 min \\
\hline
\end{tabular}

complications including shivering, nausea and vomiting. ${ }^{8}$

To test our hypothesis, we designed a randomized, double-blind comparative study with objectives to compare the anti-shivering effects of ondansetron and tramadol in patients undergoing cesarean section under spinal anesthesia and to evaluate the role of ondansetron in reducing nausea and vomiting in caesarean section patients under spinal anesthesia.

\section{Materials and Methods}

Following approval of the ethical review committee and informed patient's consent, a prospective randomized double-blind comparative study was started with 90 patients. Datafrom previous similar studies were taken into consideration ${ }^{5}$ for sample size and calculated by WHO sample size calculator. A sample of 30 patients in each group was required. ASA-I and II patients, age ranging between 18-40 years, scheduled for caesarean section under spinal anesthesia from $2^{\text {nd }}$ July 2019 to $1^{\text {st }} \mathrm{Nov} 2019$ at Frontier Corps Hospital Quetta were included. ASAIII and above, patients with cardiac arrhythmias, myocardial insufficiency, body temperature $>37.5^{\circ} \mathrm{C}$, muscular diseases, Parkinson disease and history of hypersensitivity to the study drugs agents were excluded. They were randomized into three equal groups, ondansetron ( $0 ; \mathrm{N}=31)$, tramadol $(\mathrm{T} ; \mathrm{N}=30)$ and placebo ( $\mathrm{P} ; \mathrm{N}=29$ ) respectively. Random allocation of patients in groups was undertaken by computer generated random number in sealed opaque envelopes. Blinding was achieved by using equal amounts of drugs ( $2 \mathrm{~mL}$ ), while each syringe was labeled as A, B, and C per its content. Identical coded syringes prepared by the personnel (who were not involved in the study) were randomly handed to the anesthetists, who were unaware of the identity of the drug formulations.

In the operating room, patients were monitored by noninvasive blood pressure monitoring, electrocardiogram, and pulse oximetry, then patients were placed in supine position with OT table rotated to the left between $15^{\circ}$ and $20^{\circ} \mathrm{C}$ to prevent from aortocaval compression by the uterus. The patient received 2-3 $\mathrm{L}$ oxygen/min through a face mask. Baseline axillary temperature was measured immediately after shifting to OT. Temperature of operating room was kept approximately $22^{\circ} \mathrm{C}$. All 
patients received $5-7 \mathrm{ml} / \mathrm{kg}$ with fluid warmer at $37^{\circ} \mathrm{C}$ lactated Ringer's solution before spinal anesthesia. Ten minutes before the spinal anesthesia, group $\mathrm{O}$ received $4 \mathrm{mg}$ Ondansetron, group $T$ received $20 \mathrm{mg}$ Tramadol and group $P$ received $2 \mathrm{ml}$ normal saline intravenously. Shivering score and nausea/vomiting score at $10 \mathrm{~min}, 30 \mathrm{~min}$ and $60 \mathrm{~min}$ after spinal anesthesia were recorded along with change of mean arterial pressure and mean heart rate. For spinal, after using an aseptic technique, a 25-gauge Quincke needle was inserted intrathecally via a midline approach into the L4-5 interspaces, while the patient was in a sitting position with $2.5 \mathrm{ml}$ bupivacaine $0.5 \%$ in all three groups. The primary outcomes were to evaluate score of shivering and nausea/vomiting score among all three groups on a four-point scale. Shivering scores were assessed by a blinded anesthetist. If shivering was severe, $8 \mathrm{mg}$ of ondansetron was given intravenously (IV). Hemodynamic variables were recorded.

Descriptive data was expressed as means and standard deviations (SD). Analysis of variance (ANOVA) and repeated measure analysis were used for continuous parametric variables. Within groups, comparisons were made using the Tukey's post-hoc analysis. Chi-square test was used for comparing shivering and nausea/vomiting among the groups. A p-value $<0.05$ was considered as statistically significant. Statistical analysis was carried out using SPSS Version 16 for Windows (SPSS, Chicago, IL).

\section{Results}

The mean age of patients in years, average weight, mean arterial pressure (MAP) and heart rate (HR) are described in Table 2. Shivering is significantly less $(0.35 \pm 0.59)$ in $O$ group as compared to $T$ group $(0.73 \pm 0.55)$ and $\mathrm{P}$ group $(1.90 \pm 0.84)$ ( $p$ value $<$ $0.001)$. PONV is also significantly decreased in the $O$ group $(0.25 \pm 0.53)$ as compared to in the $T$ group $(1.04 \pm 0.63)$ and in $\mathrm{P}$ group $(0.99 \pm 0.71)(p$ value<0.001).

\section{Discussion}

There are multiple reasons of spinal anesthesia induced hypothermia. Spinal anesthesia leads to an internal redistribution of heat from the core to the peripheral compartment in lower extremities, there is increased heat loss from body surfaces of the patient due to the loss of thermoregulatory

\begin{tabular}{|c|c|c|c|c|c|}
\hline Group & & Age & Weight & $\begin{array}{l}\text { Mean } \\
\text { Arterial } \\
\text { Pressure }\end{array}$ & $\begin{array}{l}\text { Heart } \\
\text { Rate }\end{array}$ \\
\hline \multirow{3}{*}{ Ondansetron } & $N$ & 31 & & & \\
\hline & Mean & 25.193 & 70.3226 & 82.6129 & 89.3226 \\
\hline & $\begin{array}{l}\text { Std. } \\
\text { Deviation }\end{array}$ & 3.7984 & 6.38429 & 5.28316 & 5.82745 \\
\hline \multirow{3}{*}{ Tramadol } & $N$ & 30 & & & \\
\hline & Mean & 25.233 & 70.5000 & 81.0333 & 89.9333 \\
\hline & $\begin{array}{l}\text { Std. } \\
\text { Deviation }\end{array}$ & 3.4309 & 6.57975 & 4.64226 & 4.89147 \\
\hline \multirow{3}{*}{ Placebo } & $\mathrm{N}$ & 29 & & & \\
\hline & Mean & 24.965 & 71.5172 & 81.6897 & 87.8621 \\
\hline & $\begin{array}{l}\text { Std. } \\
\text { Deviation }\end{array}$ & 3.0878 & 6.67950 & 4.49685 & 7.37624 \\
\hline \multirow[t]{3}{*}{ Total } & $\mathrm{N}$ & 90 & & & \\
\hline & Mean & 25.133 & 70.7667 & 81.7889 & 89.0556 \\
\hline & $\begin{array}{l}\text { Std. } \\
\text { Deviation }\end{array}$ & 3.4223 & 36.49295 & 4.81919 & 6.09174 \\
\hline
\end{tabular}

Table 3: Post-spinal Shivering and Post-operative Nausea Vomiting Score of Ondansetron

\begin{tabular}{|c|c|c|c|c|c|c|}
\hline & $\begin{array}{l}\text { Shivering } \\
10 \mathrm{~min} \\
\text { after } \\
\text { spinal }\end{array}$ & $\begin{array}{l}\text { Shivering } \\
30 \mathrm{~min} \\
\text { after } \\
\text { spinal }\end{array}$ & $\begin{array}{l}\text { Shivering } \\
60 \mathrm{~min} \\
\text { after } \\
\text { spinal }\end{array}$ & $\begin{array}{l}\text { PONV } \\
10 \mathrm{~min} \\
\text { after } \\
\text { spinal }\end{array}$ & $\begin{array}{l}\text { PONV } \\
30 \mathrm{~min} \\
\text { after } \\
\text { spinal }\end{array}$ & $\begin{array}{l}\text { PONV } \\
60 \mathrm{~min} \\
\text { after } \\
\text { spinal }\end{array}$ \\
\hline $\begin{array}{l}\text { Chi- } \\
\text { Square }\end{array}$ & $16.044^{a}$ & $19.956^{a}$ & $33.556^{a}$ & $\begin{array}{l}24.044 \\
\mathrm{a}\end{array}$ & $\begin{array}{l}26.178 \\
\text { a }\end{array}$ & $\begin{array}{l}22.267 \\
\mathrm{a}\end{array}$ \\
\hline Df & 3 & 3 & 3 & 3 & 3 & 3 \\
\hline $\begin{array}{l}\text { Asymp } \\
\text {. Sig. }\end{array}$ & .001 & .000 & .000 & .000 & .000 & .000 \\
\hline $\begin{array}{l}\text { a. } 0 \text { cell } \\
\text { minimu }\end{array}$ & $\begin{array}{l}\text { Is }(.0 \%) \mathrm{r} \\
\text { Im expec }\end{array}$ & $\begin{array}{l}\text { le expect } \\
\text { d cell fre }\end{array}$ & $\begin{array}{l}\text { ed frequen } \\
\text { quency is } 2\end{array}$ & $\begin{array}{l}\text { cies le } \\
22.5 \text {. }\end{array}$ & than & The \\
\hline
\end{tabular}

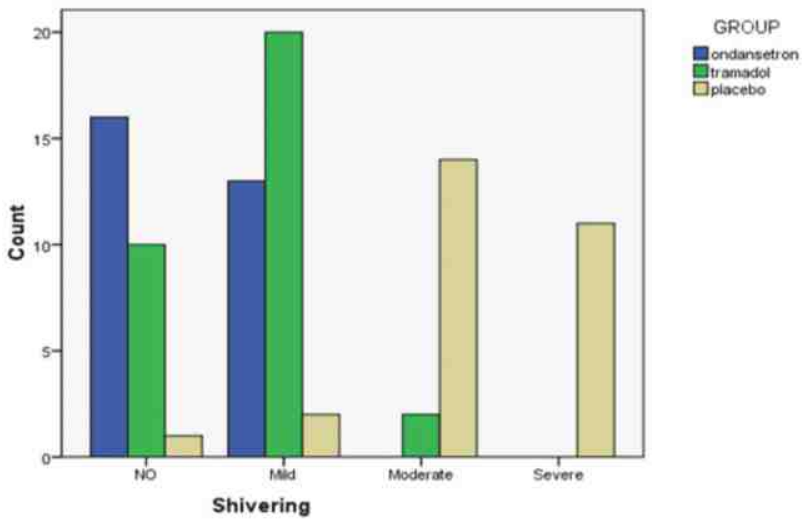

Fig 1: Frequency of shivering $10 \mathrm{~min}$ after spinal 


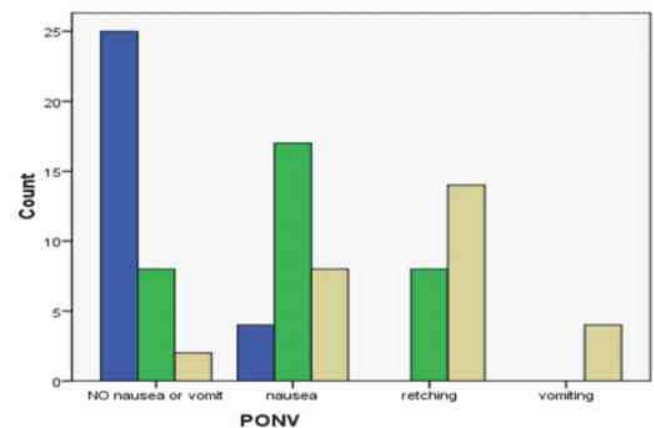

Fig 2: Frequency of PONV 10 min after spinal

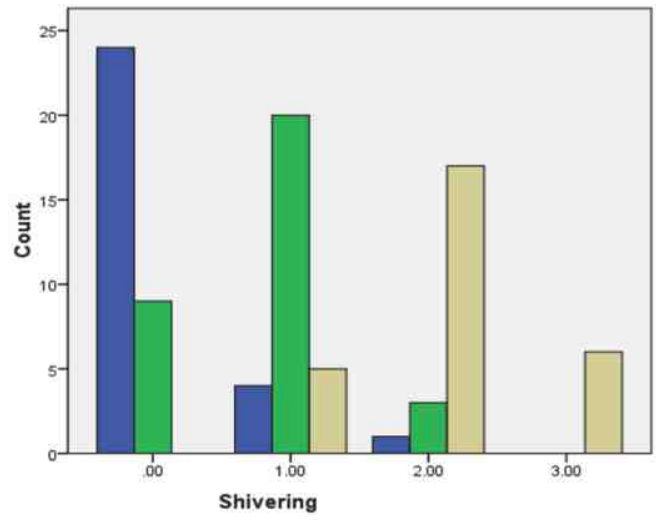

Fig 3: Frequency of shivering 30min after spinal

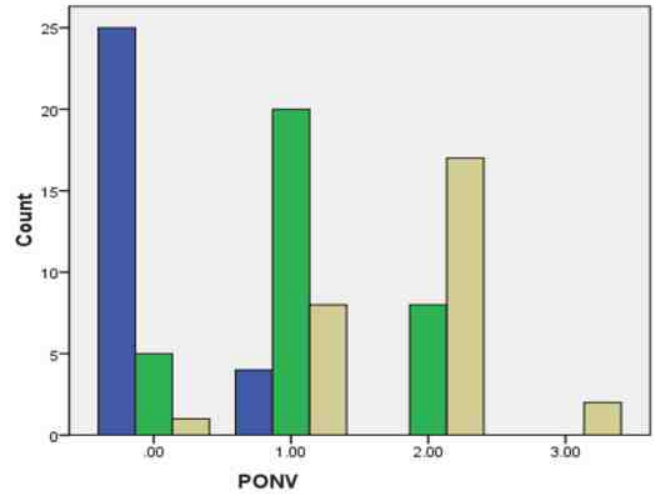

Fig 4: Frequency of PONV 30 min after spinal

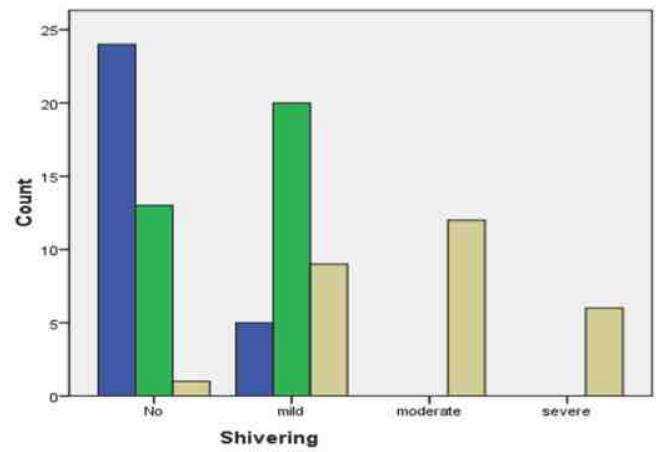

Fig 5: Frequency of shivering $60 \mathrm{~min}$ after spinal

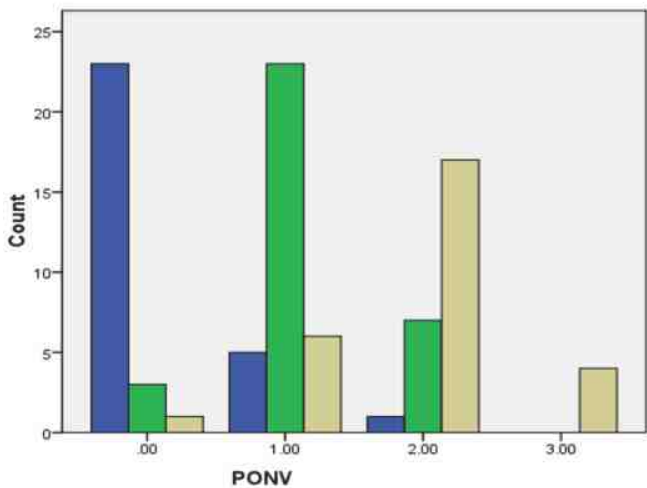

GROUP

GROUP

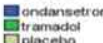

GROUP

Ondansetron - tramadol

Fig 6: Frequency of PONV 60 min after spinal

vasoconstriction below the level of the spinal blockade This altersthermoregulation mechanissm, characterized by $0.5^{\circ} \mathrm{C}$ decrease in vasoconstriction and shivering thresholds and slight increase in sweating threshold, under spinal anesthesia. ${ }^{9,10}$

Shivering varies in general and spinal anesthesia. The core body temperature decreases initially, followed by a plateau after 3-4 $\mathrm{h}$ in general anesthesia. However, no plateau appears in spinal anesthesia, because vasoconstriction is not evoked when the core temperature triggers the reset vasoconstriction threshold in spinal anesthesia. ${ }^{11}$

The anti-shivering effect of ondansetron is not dependent on intraoperative core hypothermia, i.e it inhibits thermoregulatory responses by a central mechanism. Ondansetron acts by inhibiting the 5HT3 system that results from a generalized thermoregulatory inhibition at the level of the hypothalamus where the bulk of thermoregulatory control occurs. Ondansetron also lacks hemodynamic side effects, as it prevents the combination of 5-HT released by activated platelets with 5 -HT3 receptors in the vagal nerve endings of the left ventricle, attenuates Bezold-Jarisch reflexes produced by left ventricular mechanoreceptors stimulated by $5-\mathrm{HT}$, inhibits further expansion of peripheral blood vessels, and increases venous return, thereby reducing the incidence of hypotension. ${ }^{8}$

Ondansetron, granisetron, and dolasetron, are all 5HT3-receptor antagonists. Recently, they have been used very effectively to decrease postspinal shivering. The mechanism of 5-HT3-receptor antagonists in preventing postspinal shivering is still not clearly understood but is thought to be related to inhibition of serotonin reuptake on the preoptic 
anterior hypothalamic region. ${ }^{12}$

Sajedi et al. in a prospective double-blinded study on 132 ASA I-II, patients for elective orthopedic surgery under general anesthesia, randomly assigned patients to one of the four equal groups. Group $T$ received $1 \mathrm{mg} / \mathrm{kg}$ tramadol; Group $\mathrm{G}$ received 40 $\mu \mathrm{g} / \mathrm{kg}$ granisetron, Group M received $0.4 \mathrm{mg} / \mathrm{kg}$ meperidine, and Group P received saline $0.9 \%$ as placebo. They showed that prophylactic use of granisetron $40 \mu \mathrm{g} / \mathrm{kg}$ is as effective as meperidine $(0.4 \mathrm{mg} / \mathrm{kg})$ and tramadol $(1 \mathrm{mg} / \mathrm{kg})$ in preventing postanesthetic shivering without prolonging the emergence time from anesthesia. They concluded that granisetron was as effective drug as pethidine in preventingpostanesthetic shivering. ${ }^{13}$

In a double-blinded, placebo-controlled study by Powell and Buggy, ${ }^{14}$ two doses of ondansetron $(4 \mathrm{mg}$ vs. $8 \mathrm{mg}$ ) were compared with placebo for prevention of shivering after general anesthesia, in which 82 patients (age, 18-60 years) were randomized into three groups. Postanesthetic shivering was observed in $16 / 28(57 \%)$ patients in Group C compared with 9/27 (33\%) in Group 04 ( $p=$ $0.13)$ and $4 / 27(15 \%)$ patients in Group $08(p=$ 0.003). As for dose-dependent effect of ondansetron on shivering, Powell et al. found that ondansetron was associated with a dose-dependent reduction in shivering, while the effect was not observed in pooled effect. The incidence of shivering was $10 \%$ in people weighing about $52 \mathrm{~kg}$ with low-dose ondansetron (4 mg), but Powell et al. found the incidence was $8 \%$ in people weighing about $76 \mathrm{~kg}$ with high-dose ondansetron ( $8 \mathrm{mg})^{14}$

In regional anesthesia such as spinal anesthesia, Kelsaka et al. ${ }^{15}$ reported the incidence of postspinal shivering in ondansetron $8 \mathrm{mg}$ group was $8 \%$ compared to $36 \%$ in the control group. In another study by Kim et al. ${ }^{16}$ on 52 patients who had undergone knee arthroscopy under spinal anesthesia, ramosetron, a selective serotonin 5-HT3 receptor antagonist effectively prevented shivering during spinal anesthesia. These results are corroborating with the results of our study.

In a study by Sagir et al. ${ }^{17}$ on 160 patients undergoing urological surgery under spinal anesthesia, the patients were randomly allocated to receive saline (Group P, $\mathrm{n}=40$ ), ketamine $0.5 \mathrm{mg} / \mathrm{kg}$ (Group K, $\mathrm{n}=$ 40), granisetron $3 \mathrm{mg}$ (Group $\mathrm{G}, \mathrm{n}=40$ ), or ketamine
$0.25 \mathrm{mg} / \mathrm{kg}$ + granisetron $1.5 \mathrm{mg}$ (Group KG, $\mathrm{n}=40$ ). The number of patients with observed shivering was 22 in Group P, 6 in Group G, 7 in Group GK, and 0 in Group K. The number of patients with a shivering score of 3 was statistically significantly higher in Group P compared with the other groups. They concluded that prophylactic use of ketamine and granisetron separately and in combination was effective in preventing shivering developed during regional anesthesia that emphasizes the effect of a serotonin 5-HT3 receptor antagonist on the prevention of shivering. ${ }^{17}$

Ondansetron blocks vomiting reflexes caused by the 5-HT3 receptor-induced vagal stimulation and inhibits 5-HT release in the fourth ventricle caused by vagal excitement, effectively controlling vomiting. Sahoo et al. $^{18}$ reported that intravenous $8 \mathrm{mg}$ ondansetron $5 \mathrm{~min}$ before spinal anesthesia can significantly reduce the incidences of hypotension, nausea, and vomiting in caesarean sections under spinal anesthesia and reduce the use of vasoconstrictor drugs. ${ }^{18}$

Pan and Moore compared the effect of intravenous ondansetron and metoclopramide and control group on prevention of nausea and vomiting, during the surgery and $24 \mathrm{~h}$ after, in patients who experienced cesarean with epidural anesthesia. ${ }^{19}$ They found out that in patients who had CS with epidural anesthesia, who were given $4 \mathrm{mg}$ intravenous ondansetron in a prophylactic manner, existence of vomiting and comfort was significant compared to the patients who received metoclopramide. ${ }^{20}$

Recent studies showed that serotonin receptor antagonists (ondansetron, granisetron) are highly effective for nausea, retching, and vomiting during regional anesthesia for cesarean delivery in parturients and correlated with our results. ${ }^{21,22}$ Nausea and vomiting was observed in $19 / 40$ patients $(47.5 \%)$ in the normal saline group while $2 / 40$ patients (5\%) in the ondansetron group. ${ }^{23}$

Owczuk et al. found that intravenous ondansetron attenuates spinal-induced hypotension. They advised the use of ondansetron in high-risk population, including pregnant women, in whom administration of vasoconstrictors can produce adverse effects on uterine blood flow, as well as elderly persons, in whom excess fluid administration is contraindicated due to the risk of cardiovascular 
decompensation. ${ }^{24,25}$

\section{Results}

The results of this prospective, randomized, doubleblinded comparative study demonstrate that statistically significant score of shivering was seen in Group $P$ and T as compared to Group O $(P=0.001)$. In addition, nausea and vomiting score was significantly high in Group $\mathrm{T}$ and $\mathrm{P}$ as compared to Group O.

\section{Conclusion}

Intravenous Ondansetron reduces post-spinal nausea/vomiting as well as shivering in caesarean section patients.

\section{REFERENCES}

1. Lopez MB. Postanaesthetic shivering-from pathophysiology to prevention. Romanian journal of anaesthesia and intensive care. 2018; 25: 73.

2. Khezri MB, Mosallaei MA, Ebtehaj M, Mohammadi N. Comparison of preemptive effect of intravenous ketorolac versus meperidine on postoperative shivering and pain in patients undergoing cesarean section under spinal anesthesia: A prospective, randomized, double-blind study. Caspian journal of internal medicine. 2018; 9: 151.

3. Eberhart LH, Döderlein F, Eisenhardt G, Kranke P, Sessler DI, Torossian A, et al. Independent risk factors for postoperative shivering. Anesthesia \& Analgesia. 2005; 101: 1849-57.

4. Crowley LJ, Buggy DJ. Shivering and neuraxial anesthesia. Reg Anesth Pain Med. 2008; 33: 241-52.

5. Nallam SR, Cherukuru K, Sateesh G. Efficacy of intravenous ondansetron for prevention of postspinal shivering during lower segment cesarean section: A double-blinded randomized trial. Anesthesia, essays and researches. 2017; 11: 508.

6. Roy JD, Girard M, Drolet P. Intrathecal meperidine decreases shivering during cesarean delivery under spinal anesthesia. Anesth Analg. 2004; 98: 230-4.

7. Usta B, Gozdemir M, Demircioglu RI. Dexmedetomidine for the prevention of shivering during spinal anesthesia. Clinics (Sao Paulo). 2011; 66:1187-91.

8. EbEjiro BA, Edomwonyi NP, Imarengiaye CO. Ondansetron versus tramadol in the prevention of postanaesthesia shivering following caesarean section under spinal anaesthesia. African Journal of Anaesthesia and Intensive Care. 2014; 14: 6-11.

9. Eydi M, Golzari SE, Aghamohammadi D, Kolahdouzan K, Safari S, Ostadi Z. Postoperative management of shivering: a comparison of pethidine vs. ketamine. Anesth Pain Med. 2014; 4: e15499.

10. Khezri MB, Bandari AM, Asefzade S, Atlasbaf A. The effect of diclofenac Na supp on postoperative shivering in patients undergoing elective cesarean section surgery. Pak J Med Sci. 2011; $27: 1145$
11. Panzer O, Ghazanfari N, Sessler DI, Yucel Y, Greher M, Akca $\mathrm{O}$, et al. Shivering and shivering-like tremor during labor with and without epidural analgesia. Anesthesiology. 1999; 90: 1609-16.

12. Sessler DI. Treatment: meperidine, clonidine, doxapram, ketanserin, or alfentanil Abolishes short-term postoperative shivering. Can J Anaesth. 2003; 50:635-7.

13. Sajedi P, Yaraghi A, Moseli HA. Efficacy of granisetron in preventing postanesthetic shivering. Acta AnaesthesiologicaTaiwanica. 2008; 46: 166-70.

14. Powell RM, Buggy DJ. Ondansetron given before induction of anesthesia reduces shivering after general anesthesia. Anesthesia \& Analgesia. 2000; 90: 1423-7.

15. Botros JM, Mahmoud AM, Ragab SG, Ahmed MA, Roushdy HM, Yassin HM, et al. Comparative study between Dexmedetomidine and Ondansteron for prevention of post spinal shivering. A randomized controlled trial. BMC anesthesiology. 2018; 18: 179.

16. Kim MS, Kim DW, Woo SH, Yon JH, Lee S. Effect of ramosetron on shivering during spinal anesthesia. Korean journal of anesthesiology. 2010; 58: 256.

17. Mohammadi SS, Jabbarzadeh S, Movafegh A. Efficacy of granisetron on prevention of shivering, nausea and vomiting during cesarean delivery under spinal anesthesia: A randomized double-blinded clinical trial. Journal of Obstetric Anaesthesia and Critical Care. 2015; 5: 22.

18. Baig R, Shah AA, Khurshid T, Abid L, Tariq Z. Use of Ondansetron for Prevention of Spinal Induced Hypotension. Journal of Islamabad Medical \& Dental College. 2017; 6: 208-13.

19. Pan $\mathrm{PH}$, Moore $\mathrm{CH}$. Comparing the efficacy of prophylactic metoclopramide, ondansetron, and placebo in cesarean section patients given epidural anesthesia. J Clin Anesth. 2001; 13: 430-5.

20. Erhart LH, Högel J, Seeling W, Staack AM, Geldner G, Georgieff M. Evaluation of three risk scores to predict postoperative nausea and vomiting. Acta Anaesthesiol Scand. 2000; 44: 480-8.

21. Balki M, Carvalho JC. Intraoperative nausea and vomiting during cesarean section under regional anesthesia. Int J ObstetAnesth. 2005; 14: 230-41.

22. Hesketh PJ. Comparative review of 5-HT3 receptor antagonists in the treatment of acute chemotherapyinduced nausea and vomiting. Cancer Invest. 2000; 18: 163-73.

23. Leeser J, Lip H. Prevention of postoperative nausea and vomiting using ondansetron, a new, selective, 5-HT3 receptor antagonist. Anesth Analg. 1991; 72: 751-5.

24. Gao L, Zheng G, Han J, Wang Y, Zheng J. Effects of prophylactic ondansetron on spinal anesthesia-induced hypotension: a meta-analysis. International journal of obstetric anesthesia. 2015; 24: 335-43.

25. Tubog TD, Kane TD, Pugh MA. Effects of ondansetron on attenuating spinal anesthesia-induced hypotension and bradycardia in obstetric and nonobstetric subjects: a systematic review and meta-analysis. AANA J. 2017; 85: 113-22. 